\title{
High Temperature 0xidation Resistance on Heat-Resistant Alloys with Small Additions of Reactive Elements
}

\author{
微量の活性元素添加による耐熱合金の高温耐酸化性改善
}

\author{
Tadaaki Amano, Kaoru Michiyama, Yasuhiko Nakajima, Nobutaka Suzuki, \\ Hideyoshi Matsumoto, Takaya Masumura and Hiroshi Yokota \\ Department of Materials Science and Ceramic Technology, \\ Shonan Institute of Technology, Tsujidou-Nishikaigan, Fujisawa, 251 Japan \\ (Accepted for publication 18 Nobember 1993 )
}

\section{1. 緒言}

近年, 自動車などの排気ガスにより，地球の温暖 化やオゾン層の破壞といった環境問題がクローズアッ プされてきた。自動車排気ガスの清浄化のため, 40-50 $\mu \mathrm{m}$ の箔にした耐熱合金を八チの巣状にし，こ れに白金を含む触媒をつけた浄化装置が注目を浴び てきている。この耐熱合金は微量の活性元素を含む $\mathrm{Fe}-\mathrm{Cr}-\mathrm{A} 1$ 合金であり，合金表面に密着性のある $\alpha-\mathrm{Al}_{2} 0_{3}$ 皮膜を生成する。

本研究では，合金表面に $\alpha-\mathrm{Al}_{2} \mathrm{O}_{3}$ 皮膜を生成する $\mathrm{Fe}-20 \mathrm{Cr}-4 \mathrm{~A} 1$ 合金およびこれに微量の活性元素（Y, Pr, Gd, Ho, Ti, Zr, Hf) を添加した合金について, 1473-1673Kに招ける高温酸化実験を行い，これらの 活性元素が質量増加量および表面酸化皮膜の密着性 にどのような影響をおよぼすかを明らかにすること を目的とした。

\section{2. 実験方法}

Fe-20Cr-4A1およびこれに0.1または0.5\%のY, Pr Gd，Ho，Ti，Zr，Hfを添加した合金をアーク溶解法に より溶製し，その後熱間・冷間圧延により約 $0.5 \mathrm{~mm} の$ 厚さにし,ついで約 $10 \mathrm{~mm} \times 20 \mathrm{~mm}$ の板状試片を作成し た（合金名は無添加合金をA4，希土類元素，Ti，Zr， Hf添加合金では, 分析結果より得られた各元素の含有 \%の\%を除いて略称する。）。さらに1373Kで18.0ksの 真空焼鈍しを行い，エメリ一紙およびダイヤモンド ペーストを用いて合金表面を鏡面仕上げし，アルコー ル中で超音波洗浄後供試材とした。酸化は酸素中1473, 1573 および1673Kで18.0ks 間行った。酸化後質量増加 量を計算し，ついで酸化後の表面酸化皮膜形態および 酸化皮膜の結晶相をSEMおよびX線回折装置を用いてそ れぞれ明らかにした。表面酸化皮膜および酸化皮膜/合 金界面の元素濃度分布についてはEPMAを用いて観察し た。

\section{3. 実験結果}

3.1 微量の希土類元素(Y, Pr, Gd, Ho)を添加した $\mathrm{Fe}-20 \mathrm{Cr}-4 \mathrm{~A} 1$ 合金の高温酸化

Figure 1 に0.1\%希土類元素を添加した合金の質量増 加量を示す。A4の表面酸化皮膜はどの酸化温度であ酸 化後剝離し飛散するので, その質量増加量の值には不 明確な点を含んでいる。0.07Yの質量増加量はA4のそ

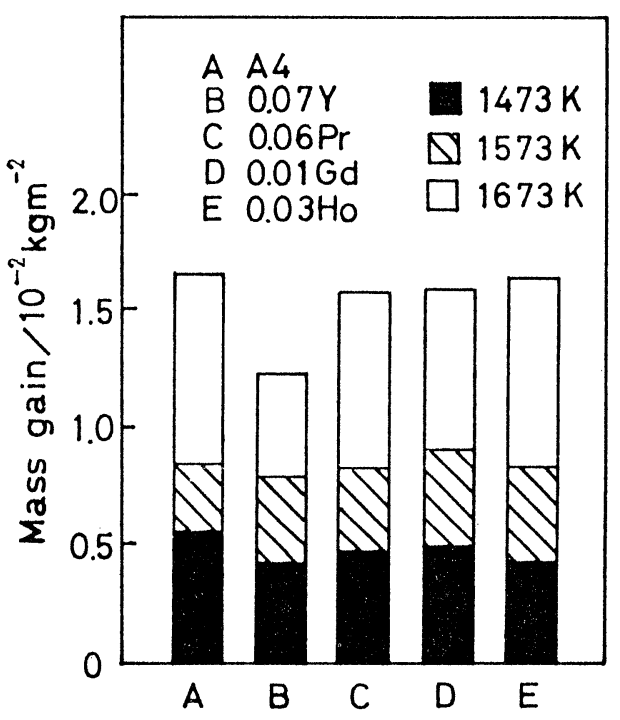

Figure 1 Mass gain of $\mathrm{Fe}-20 \mathrm{Cr}-4 \mathrm{Al}$ alloys with small additions of rare earth elements oxidized in $\mathrm{O}_{2}$ for $18.0 \mathrm{ks}$ at 1473,1573 and $1673 \mathrm{~K}$.

れと比べて著しく低減し，0.06Pr，0.01Gd および $0.03 \mathrm{Ho}$ 質量増加量はA4より僅かに小さい。この結果 はYの微量添加が何らかの理由によって陽イオンある いは陰イオンの拡散を遅くすることを示唆している。 表面酸化皮膜はいずれの酸化温度おょびいずれの合金 においてあ $\alpha-A 1203$ が支配的であった。A4上に生成し た酸化皮膜は酸化後表面全体加剥離した。これに対 して希土類元素を添加した合金の酸化皮膜はおおむ的 平滑であり，表面酸化皮膜の密着性が改善された。 3.2 微量の Ti，ZrまたはHfを添加した $\mathrm{Fe}-20 \mathrm{Cr}-4 \mathrm{Al}$ 合金の高温酸化

$0.10 \mathrm{Ti}$ および0. $10 \mathrm{Hf}$ では表面酸化皮膜の剝離が微 量認められたが、これらの合金の質量増加量はおお む称 $0.10 \mathrm{Hf}<0.51 \mathrm{~T} \mathrm{i}<0.10 \mathrm{Ti}<0.10 \mathrm{Zr}<0.43 \mathrm{Hf}$ く $0.51 \mathrm{Zr}$ の順に増加した。 $\mathrm{i}$, Z ZrまたはHfを添加 したいずれの合金においてすA4より表面酸化皮膜の 密着性が改善された。 